\title{
Thierry Laget, Portraits de Stendhal
}

\section{Michel Arrous}

\section{(2) OpenEdition}

\section{Journals}

\section{Édition électronique}

URL : http://journals.openedition.org/studifrancesi/7621

DOI : 10.4000/studifrancesi.7621

ISSN : 2427-5856

\section{Éditeur}

Rosenberg \& Sellier

\section{Édition imprimée}

Date de publication : 1 décembre 2009

Pagination : 645

ISSN : 0039-2944

\section{Référence électronique}

Michel Arrous, "Thierry Laget, Portraits de Stendhal », Studi Francesi [En ligne], 159 (LIII | III) | 2009, mis en ligne le 30 novembre 2015, consulté le 08 janvier 2021. URL : http://journals.openedition.org/ studifrancesi/7621 ; DOI : https://doi.org/10.4000/studifrancesi.7621

Ce document a été généré automatiquement le 8 janvier 2021.

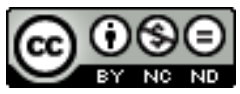

Studi Francesi è distribuita con Licenza Creative Commons Attribuzione - Non commerciale - Non opere derivate 4.0 Internazionale. 


\title{
Thierry Laget, Portraits de Stendhal
}

\author{
Michel Arrous
}

\section{RÉFÉRENCE}

THIERRY LAGET, Portraits de Stendhal, Paris, Gallimard, 2008, «L'un et l'autre», pp. 206.

1 Cinquante-trois portraits formant une petite suite ponctuée par autant de dates qui résonnent à la mémoire des happy few. La silhouette d'un gros bonhomme qui dicte un roman à un certain Bonavie, puis la vie dans son défilement capricieux d'instants heureux ou malheureux: un soir de brumaire à Paris, un conscrit bravache au fort de Bard, la révélation de Cimarosa, et bien d'autres consignés régulièrement à partir de 1832. Thierry Laget a voulu retracer la vie d'Henry Beyle, non pas à la manière d'un biographe appliqué, mais en choisissant une journée, un lieu, voire un objet (qu'on pense à la machine à ongles ou aux lunettes vertes), en espion doué d'une fort louable empathie. 